\title{
Tinjauan Penalaran IImiah Pada Penemuan-Penemuan Sains Yang Tak Disengaja (Serendipity)
}

\author{
Lusia Narsia Amsad \\ Program Studi Pendidikan Kimia \\ Universitas Cenderawasih, Papua, Indonesia \\ e-mail: Lusianarsiaamsad@gmail.com
}

\begin{abstract}
Abstrak
Banyak penemuan tak terduga (kebetulan) memiliki dampak mendalam dalam pembelajaran sains. Berdasarkan tipologi serendipity dapat dikompilasi menjadi serendipity murni dan pseudo serendipity. Selain itu, Serendipity murni jika kita dikaitkan dengan penalaran ilmiah diketahui bahwa itu cenderung terjadi sesuai dengan inferensi induktif, inferensi abduktif, sedangkan kebetulan semu sebagian besar terjadi oleh inferensi deduktif. Oleh karena itu, berdasarkan penalaran ilmiah, kebetulan dapat dikelompokkan menjadi: 1) Kesempatan yang muncul dari kesimpulan induktif; 2) Serendipity yang berasal dari kesimpulan deduktif; dan 3) Serendipity yang muncul dari inferensi abduktif yang menggarisbawahi konstruksi teori berdasarkan fakta.
\end{abstract}

Kata kunci : Serendipity murni, Pseudo serendipity, Penalaran ilmiah

\begin{abstract}
Many unexpected discovery (serendipity) have a profound impact in science learning. Based on the serendipity typology can be compiled into pure serendipity and pseudo serendipity. Moreover, pure Serendipity if we associated with the scientific reasoning known that it tend to be occur according to inductive inference, abductive inference, while the pseudo serendipity mostly happened by deductive inference. Therefore, based on the scientific reasoning the serendipity can be grouped into: 1) Serendipity that arise from inductive inference; 2) Serendipity that come from deductive inference; and 3) Serendipity that appear from abductive inference that underline the theory construction based on the facts.
\end{abstract}

Key Words: Pure serendipity, Pseudo serendipity, Scientific reasoning

\section{Pendahuluan}

Sejarah sains pada dasarnya merupakan sejarah pikiran umat manusia, terlepas dari asal usul kebangsaan maupun asal mula negara. Lintasan sejarah sains yang terbaik adalah mengikuti pembagian kurun waktu dari satu zaman yang terdahulu ke zaman berikutnya (Muksin ,2016). Perkembangan sains akhir-akhir ini semakin meningkat didukung adanya berbagai penemuan-penemuan di bidang sains. Penemuan sains tersebut seringkali menjadi target dari setiap penemuan yang dilakukan oleh para ilmuwan, namun banyak pula penemuan sains yang justru terjadi secara tak terduga atau yang sering disebut sebagai serendipity. Bagi para ilmuwan penemuan yang tidak sengaja ini dapat dianggap terjadi sebagai "efek dari kepak sayap kupu-kupu (butterfly effect)" istilah dalam "Teori Chaos" (Chaos Theory) yang berhubungan dengan "ketergantungan yang peka terhadap kondisi awal" (sensitive dependence on initial conditions), dikemukakan pertama kali oleh Edward Norton Lorenz yakni gagasan bahwa perubahan kecil dalam kondisi awal dapat menyebabkan variasi drastis dalam jangka panjang. Bahkan berdampak terhadap munculnya suatu penemuan yang tidak diharapkan tetapi memiliki manfaat yang besar bagi kelangsungan hidup banyak orang (Ghys, Ettianne, 2012).

Banyak yang meyakini bahwa perkembangan sains dan teknologi dari masa ke masa berlangsung secara "linier", artinya berkembang semakin lama semakin maju. Jika dihitung sejak jaman akademia (Plato-Socrates-Aristoteles) - sekitar 2500 tahun yang lalu - ketika tradisi akademik (mengajarkan dan men-dokumentasi ilmu-pengetahuan) mulai dibangun secara "formal", mungkin linieritas perkembangan sains dan teknologi memang merupakan keniscayaan sejarah. Dengan berkembangnya tradisi akademik ke seluruh dunia, maka tidak 
pernah lagi manusia pada suatu jaman kurang ber-ilmu daripada manusia pada jaman sebelumnya. Peradaban manusia dari hari ke hari semakin memajukan sains dan teknologi, tanpa pernah lagi surut ke belakang (Rhisa ,2015).

Kemajuan sains dan teknologi zaman kontemporer sekarang ini, tidak bisa lepas dengan perkembangan, penemuan dan kemajuan sains dan teknologi pada abad kejayaan ilmu pengetahuan umat Islam, yaitu pada pada abad kejayaan kekhalifahan Abbasiyah di Bagdad (Hamid ,2015). Hakikat sains atau Nature of Science (NOS) merupakan pengetahuan tentang epistemologi (metode) dari sains, proses terjadinya sains, atau nilai dan keyakinan yang melekat untuk mengembangkan sains (Khalick dkk,1998: 418). Nature of science direpresentasikan dengan 10 karakter. Dua karakter melekat pada substansi sains dan delapan karakter melekat pada epistemologi pengembangan sains. Pemahaman tentang NOS dipandang sangat perlu untuk standar kelulusan dari pendidikan sains sebelum memasuki perkuliahan sehingga memiliki literasi sains (Khalick dkk, 2008: 835). Bahkan Mullis dan Jenkins (dalam Meichtry, 1993: 432) menyatakan bahwa pemahaman NOS yang baik dapat memberikan kemampuan intelektual yang dibutuhkan oleh seseorang untuk mengembangkan sains dan teknologi (Ratnawati,2017).

Di dalam dunia sains modern maupun posmodern, permasalahan ontologis yang mendasar adalah kritik tentang ilmu logika. Logika berpikir, sempat 'diagungagungkan' oleh sains untuk menjelaskan hubungan sebab akibat dalam realitas hidup manusia. Namun dalam perkembangannya, penjabaran tentang logika menurut 'sains' tidak dapat dijadikan parameter mutlak, oleh karena berbagai logika tersebut terkait dengan berbagai sumber ontologi, yang pada akhirnya melahirkan bidang ilmu lain atau epistemologi tertentu (Gunarti ,2013). Sains berkaitan dengan cara mencari tahu tentang alam secara sistematis sehingga sains bukan hanya penguasaan kumpulan pengetahuan yang berupa fakta-fakta, konsep-konsep atau prinsip saja. (Depdiknas, 2006d: 409). Pendidikan sains diarahkan untuk "mencari tahu" dan "berbuat" sehingga dapat membantu Peserta didik untuk memperoleh pemahaman yang lebih mendalam tentang alam sekitar ( Eka ,2016). Perkembangan sains tidak terlepas dari perkembangan teknologi, politik, ekonomi, sosial dan filsafat di masyarakat. Demikian juga perkembangan sains pada abad ke-20. Sejarah mencatat terjadi perubahan yang besar pada abad ke-20 ini. Semua perubahan tersebut berkembang dari filsafat yang dianut oleh masyarakat hampir di seluruh dunia di masa sebelumnya (Arif ,2016).

Adanya berbagai penemuan yang tak disengaja (serendipity) yang sangat berdampak dalam pembelajaran sains tentu membuat kita berpikir apakah adakah suatu penalaran ilmiah yang dapat dihubungkan dengan semua penemuan yang ada? Pada dasarnya penalaran ilmiah terbagi menjadi dua pola penalaran yakni penalaran induktif (inductive reasoning) maupun penalaran deduktif (deductive reasoning). Penalaran induktif bersifat empiris yang merupakan penarikan kesimpulan umum dari kasus-kasus individual atau dapat dikatakan bersifat dari pernyataan-pernyataan yang bersifat khusus ke umum. Sementara penalaran deduktif merupakan kesimpulan dari pernyataan-pernyataan yang kebenarannya telah dipastikan. Selain itu adapula penalaran abduktif (abductive reasoning) yaitu proses inferensi logis dari obseravsi menuju pada suatu teori (Mannoia, 1980). Dalam hal ini penggabungan dari kedua pola penaran tersebut membentuk suatu logika ilmiah (sciencetific logic) yakni sifat rasionalisme dan empirisme kedua-duanya digunakan. Sebab itu kita perlu mengetahui bagaimana hubungan penalaran ilmiah dalam setiap penemuan-penemuan sains yang dapat terjadi secara tak terduga tersebut.

Serendipity umumnya digunakan sebagai istilah untuk menyatakan suatu peristiwa kecelakaan yang membahagiakan (Ferguson, 1999) atau diartikan juga sebagai suatu temuan tentang sesuatu hal tanpa perlu dicari (Austin, 2003), dan identik juga dengan "suatu kejutan yang menyenangkan" (Tolson, 2004). Bahkan The New Oxford Dictionary of English mendefinisikan sebagai "terjadinya dan berkembangnya peristiwa kebetulan dengan cara yang menyenangkan atau menguntungkan". Sumber ini juga mendefinisikan kesempatan sebagai peristiwa yang terjadi tanpa adanya suatu desain yang jelas (secara acak atau sengaja), atau salah satu dari yang penyebabnya tidak diketahui (Mayr, 1998). Umumnya penelitian ilmiah tentang serendipity dianggap sebagai "wacana anekdot, dan jarang yang sistematis" (Campanario, 1996; Bandura, 1982, 1998), biasanya mengacu pada peristiwa kebetulan. Namun kita dapat mengutip pendapat dari Burt (2004) :" Bahwa serendipity merupakan cara untuk melihat jembatan yang dapat menghubungkan walaupun orang lain hanya melihat ada lubang besar yang tidak terjangkau."

Kata serendipity dimunculkan pertama kali dari cerita Sir Horace Walpole dalam surat yang dikirim ke teman dan sepupu jauh Sir Horace Mann pada 28 Januari 1754. Dia 
menceritakan kisah bahwa:" Pada abad ke-16 dari tiga pangeran dari Serendip (Sri Langka) yang sedang berjalan di gurun dan bertemu dengan seorang pengendara unta. Pengendara unta tersebut telah kehilangan unta, ia bertanya apakah ketiga pangeran mungkin telah melihat unta tersebut. Meskipun mereka tidak pernah melihat hewan yang hilang itu, ketiga pangeran dapat dengan akurat menggambarkan ciri unta milik pengendara unta tersebut dan orang yang membawa unta tersebut. Mereka mengatakan jika satu mata unta tersebut buta, ada bagian gigi unta yang tidak lengkap, dan satu kakinya lumpuh. Mereka mengemkakan juga bahwa unta itu membawa muatan mentega di satu sisi dan madu di sisi lain, dan ditunggangi oleh seorang wanita hamil. Deskripsi mereka begitu akurat, sesuai dengan kenyataannya, sehingga pemilik unta itu menuduh pangeran telah mencuri untanya, dan mendakwa mereka di pengadilan kaisar. Namun, di hadapan Kaisar Behram, menjadi jelas bahwa ketiga pangeran sepenuhnya tidak bersalah. Mereka menjelaskan bahwa mereka berpikir jika unta tersebut buta di bagian mata sebelah kanan karena rumput yang telah kelihatan dimakan unta hanya pada sisi kiri jalan. Mereka menyimpulkan bahwa unta itu tidak memiliki gigi pada bagian tertentu dari bekas rumput yang dikunyah tersebar di seluruh jalan. Jejak kaki unta tersebut tampaknya menunjukkan bahwa hewan itu lumpuh dan menyeret satu kakinya. Ditemukan adanya semut di salah satu sisi jalan dan lebah di sisi lain, mereka menyimpulkan bahwa unta harus telah membawa muatan mentega di sisi semut, dan madu di sisi yang lain. Akhirnya, mereka juga menyimpulkan bahwa orang yang membawa unta tersebut adalah seorang wanita hamil karena adanya bekas urine yang tercium seringkali di tanah" (Merton dan Barber, 2004). Berdasarkan cerita ini terlihat jelas jika para pangeran melakukan lebih dari mengamati setiap peristiwa yang dianggap sebagai suatu kebetulan. Kisah ini jika diamati bahwa terdapat berbagai hubungan namun semuanya muncul secara acak, tetapi dapat disatukan dan disimpulkan oleh ketiga pangeran tersebut (De Rond, 2005).

Kuhn menyatakan bahwa:" Proses penemuan ilmiah dimulai dengan kesadaran terhadap anomali, atau faktor unsought: Pengakuan bahwa alam entah bagaimana melanggar paradigma yang diinduksi mengatur ilmu pengetahuan normal" (Kuhn, 1970). Kuhn mengakui peran serendipity dalam pengembangan teori sendiri tentang struktur revolusi ilmiah. Dengan demikian, tampaknya kejadian kebetulan saja tidak cukup menjelaskan penemuan baru secara ilmiah. Konsisten dengan pepatah yang sering dikutip Pasteur, Rossman, menulis pada 1930an, bahwa:" Kesempatan atau kecelakaan memainkan bagian yang sangat kecil dalam menciptakan hari ini." Dapat dilihat bahwa penemu menggunakan metode yang disengaja dan sistematis dalam membuat penemuan mereka. Hanya 75 dari 259 penemu yang ditanya apakah kebetulan atau kecelakaan memainkan peran apapun dalam penemuan para imuwan maka mereka akan mengiyakan. Sebuah studi yang cermat cerita-cerita tentang penemuan disengaja, bagaimanapun, akan mengungkapkan fakta bahwa beruntung kecelakaan hanya terjadi pada orang-orang yang pantas. Dalam hampir semua kasus ditemukan bahwa kecelakaan terjadi yang menuju serendipity hanya setelah adanya pencarian terus-menerus dan dilakukan dengan hati-hati untuk mencapai apa yang diinginkan (dikutip dalam Merton dan Barber, 2004). Untuk itu pada artikel ini akan meninjau penalaran ilmiah dari penemuanpenemuan yang tidak disengaja (serendipity) dalam sains.

\section{Metode}

Pada penulisan artikel ini menggunakan studi literatur. Peninjauan terhadap buku-buku, jurnal dan makalah dilakukan untuk dapat membuat suatu telaah mendalam -penemuan. Hal ini dimaksudkan untuk dapat memperoleh informasi yang menghubungkan bagaimana penalaranpenalaran ilmiah yang dilakukan para ilmuwan pada penemuan-penemuan yang tidak disengaja (serendipity) yang sangat berperan dalam bidang sains.

\section{Hasil dan Pembahasan}

\section{Tujuan terhadap penemuan yang tak disengaja dalam bidang Biologi Penisilin}

Penemuan yang paling penting dan tak disengaja dalam dunia Biologi adalah penemuan penisilin. Penemuan ini terjadi pada masa perang dunia I dimana pada saat itu digunakan fenol sebagai antiseptik dalam proses penyembuhan luka. Saat itu Fleming dan temannya Wright ditempatkan untuk membantu tentara yang terluka di Prancis. Hal ini mengarahkan Fleming pada penemuan tidak sengaja tahun 1922 yaitu penemuan adanya suatu antibiotik yang membunuh bakteria tetapi tidak membunuh sel darah putih. Saat itu Fleming menderita flu dan sedang membuat pembiakan dari ingusnya. Ketika Flemming sedang mengamati cawan petri 
yang berisi bakteria kuning, air matanya jauh ke atas cawan petri tersebut. Pada hari berikutnya ketika Fleming memeriksa pembiakan, ia menemukan adanya bagian yang bersih di tempat jatuhnya air mata. Pengamatan yang cermat dan keingintahuannya menuntunnya pada kesimpulan yang benar. Air mata mengandung zat yang menyebabkan adanya perusakan cepat (lysis) dari bakteria tersebut tetapi tidak berbahaya bagi jaringan tubuh dan enzim tersebut dinamakan lisozom. Kemudian pada tahun 1928, ketika Fleming sedang meneliti influenza. Fleming sedang melakukan kegiatan laboratorium rutin yang melibatkan pengujian mikroskopis terhadap pembiakan bakteria yang berkembang pada cawan petri. Fleming memperhatikan adanya sebuah bidang yang sangat bersih di satu cawan petri. Pengujian itu menunjukkan bahwa bidang yang bersih itu dikelilingi sebuah bercak tempat jatuhnya sedikit jamur ke dalam cawan petri, yang nampaknya terjadi ketika cawan petri tidak ditutup. Berdasarkan pengalamannya dengan lisozom, Fleming menyimpulkan bahwa jamur tersebut mengandung sesuatu yang dapat mematikan bakteri stafilokokus yang ada. Kemudian Fleming memisahkan jamur tersebut dan mengenalinya sebagi anggota gen Penicillium, dan ia menamakan zat antibiotik yang dihasilkannya sebagai penicilin. Kemudian ia mengatakan: "Ada ribuan jamur yang berbeda-beda, dan jatuhnya jamur yang tepat pada waktu yang tepat dan saat yang tepat adalah suatu kesempatan yang rasanya sama seperti memenangkan suatu lotere". Untungnya, bakteri yang dimatikan penicilin adalah bakteri yang menyebabkan infeksi umum dan serius pada manusia (Robert, 2004).

\section{Struktur DNA}

Pseudoserendipity dengan cara variasi acak: DNA Dalam penemuan kebetulan ini, kesempatan memainkan peran jauh lebih signifikan. James Watson dan Francis Crick dianugerahi hadiah nobel untuk penemuan ini pada 1962. Penemuan utama adalah penentuan Watson dari sifat yang tepat dari dua pasangan basa (A dengan T, G dengan C). Dia melakukan ini bukan dengan logika, tapi oleh serendipity. Dalam arti penemuan Watson dan Crick adalah keberuntungan, tapi kemudian sebagian besar penemuan memiliki unsur keberuntungan di dalamnya. Titik yang lebih penting adalah bahwa Watson sedang mencari sesuatu yang signifikan dan segera mengakui pentingnya pasangan yang benar ketika ia memasangkannya secara kebetulan (Watson \& Crick, 1953). Beberapa waktu kemudian, muncul ide yang mulanya dianggap sepele. Ketika Watson menyadari adanya implikasi yang berpotensi untuk mendalami struktur DNA dimana residu adenin membentuk ikatan hidrogen mirip dengan yang ditemukan dalam kristal dari adenin murni (Watson, 1999). Dengan demikian, Watson menyimpulkan, DNA mungkin terdiri dari dua rantai dengan urutan basa yang identik diselenggarakan bersama oleh ikatan hidrogen antara pasangan basa identik. Crick dan Watson, menyatakan bahwa sebagian besar buku pelajaran representasi dari bentuk tautomerik guanin dan timin yang sangat mustahil (De Rond, 2005).

\section{Vaksinasi cacar}

Sampai abad kesembilan belas, salah satu malapetaka bagi umat manusia adalah penyakit cacar. Namun berkat serendipity, vaksinasi cacar ditemukan oleh Edwar Jenner maka penyakit teersebut dapat diatasi. Edward Jenner tjdak menemukan vaksin cacar sebagai hasil dari suatu kerja keras yang panjang dan melelahkan di suatu laboratorium. Jenner hanya mengingat pernyataan dari seorang wanita pemerah susu sapi bahwa wanita itu tidak akan terkena penyakit cacar karena wanita tersebut sudah pernah mengidap penyakit cacar sapi, pada waktu itu usia Jenner 19 tahun. Pernyataan tersebut diingatnya kembali pada saat ia menjadi dokter dan membuatnya mengadakan penyelidikan yang lebih seksama terhadap para wanita pemerah susu sapi dan ternyata mereka tidak pernah tertular penyakit cacar walaupun mereka juga sedang merawat keluarganya yang menderita penyakit cacar. Akhirnya timbullah gagasan untuk menginokulasi pasien dengan cacar sapi untuk mencegah mereka dari penyakit cacar yang jauh lebih mematikan. Fakta bahwa penyakit cacar pada sapi dapat memberi kekebalan pada penyakit cacar bagi manusia tentu saja merupakan suatu serendipity. Tanpa Edward Jenner perlu berupaya keras untuk menghasilkannya, Edward Jenner dikatakan hanya memiliki penilaian yang baik untuk memahami nilai cacar sapi dan memanfaatkannya (Robert, 2004).

\section{Tujuan Terhadap Penemuan yang tak disengaja dalam bidang Fisika}

Baterei Listrik

Berawal dari adanya percobaan yang tidak sengaja yang dilakukan oleh Luigi Galvani (1737-1798) pada tahun 1786 mengamati bahwa kaki kodok yang telah dipotong menunjukkan 
gerakan kejut saat diletakkan di atas meja di dekat sebuah generator elektrostatik (pengamatan ini pernah dilakukan 30 tahun sebelumnya oleh Floriano Caldani). Galvani menindaklanjuti pengamatannya dengan sebuah studi yang disebut "listrik binatang". Dia menggantungkan kaki kodok pada sebuah pagar besi di balkon dengan sebuah gantungan dari kuningan dan mencatat bahwa bagian bawah dari kaki itu berkontraksi ketika bersentuhan dengan bagian lain dari pagar logam tersebut (pengamatan inipun pernah dilakukan oleh Jan swamerdam di Belanga kurang lebih seratus tahun yang lalu). Laporan-laporan Galvani membangkitkan minat seorang ilmuwan Italia lainnya yaitu Allesandro Volta. Volta berpendapat bahwa adanya gerakan kejut yang dilakukan oleh kaki kodok yang telah dipotong itu diakibatkan adanya beda potensial antara dua logam yang tak sejenis (gantungan logam kuningan yang bahan utamanya adalah tembaga dengan logam besi dari pagar balkon tersebut, yang tak sengaja terhubung oleh jaringan-jaringan kaki kodok tersebut. Bagi Volta, otot dan saraf-saraf kodok mewakili suatu elektroskop yang sangat sensitif, yakni elektroskop yang mampu mendeteksi adanya suatu arus yang jauh lebih lemah daripada arus-arus yang sudah pernah dipelajari dengan peralatan-peralatan yang ada. Volta membuktikan teorinya tentang beda potensial listrik dari logam-logam yang tak sejenis dengan menciptakan baterei praktis yang pertama yang diungkapkannya pada Royal Society di London pada tahun 1800. Baterei ini merupakan sumber pertama dari arus lisrik yang bermanfaat (Robert, 2004).

\section{Elektromagnetisme}

Menjelang akhir abad ke-18, Charles Augustin de Coulomb menemukan bahwa hukum gaya berlaku terbalik, yang sebelunya salah diamati oleh Galvani. Tetapi dalam hal ini belum diemukan adanya hubungan antara magnetisme dan listrik. Akhirnya pada tahun 1820 ditemukan oleh Hans Christian Oersted mendapatkan adanya penemuan yang tak disengaja bahwa sebuah kawat yang diletakkan di atas sebuah kompas akan membelokkan jarum magnet dari kompas tersebut, dan melalui pengamatan Oersted yang lebih mendalam diketahui bahwa hal tersebut disebakan oleh adanya arus listrik, akhirnya serendipity ini mengarahkan pada adanya penemuan William Sturgeon dari Inggris pada tahun 1825 tentang penemun elektromagnet praktis (Robert, 2004).

\section{Sinar $X$}

Diawali dengan adanya penemuan dari Sir William Crookes yang menjelaskan tentang sinar katode memacu berbagai penemuan - penemuan lainnya dari para ilmuwan. Termasuk salah satunya adalah fisikawan Jerman Wilhelm Röentgen (tahun 1985) bekerja dengan tabung sinar katoda. Tabung itu tertutup, tapi layar fluorescent terdekat masih akan menyala saat tabung itu ditutup dan ruangannya gelap. Terdapat titik-titik sinar lemah yang menerangi layar. Röentgen mencoba menghalangi sinar, tapi kebanyakan berbagai benda yang ia ditempatkan di depan tidak ada bedanya. Namun, ketika ia meletakkan tangannya di depan tabung, ia melihat ia bisa melihat tulang-tulang di gambar yang diproyeksikan ke layar.tabung diganti dengan plat fotografi, dan gambar X-ray pertama yang diproduksi (Robert, 2004).

\section{Tinjauan Terhadap Penemuan yang tak disengaja dalam bidang Kimia Radioaktivitas}

IImuwan Perancis Henri Becquerel bekerja pada bahan berpendar, yang bersinar dalam gelap setelah terpapar cahaya. Penemuan secara kebetulan terjadi selama percobaan yang melibatkan kristal uranium. Dia percaya sinar matahari adalah alasan bahwa kristal akan membakar gambar pada piring fotografi. Suatu hari badai pada tahun 1896, ia memutuskan untuk meninggalkan pengamatan kristal pada hari itu dan melanjutkan eksperimennya saat cuaca lebih baik. Beberapa hari kemudian, ia mengambil kristal keluar dari laci gelap. Gambar dibakar di piring itu "berkabut". Hal ini berarti kristal itu masih memancarkan sinar, meskipun kurangnya sinar matahari. Sudah jelas bahwa ada bentuk radiasi yang tak terlihat yang bisa melewati kertas, menyebabkan piring untuk bereaksi seperti jika terkena cahaya. Penelitiannya dilanjutkan oleh Pierre dan Marie Curie, yang bernama radioaktivitas fenomena. Penemuan radioaktivitas memicu adanya penemuan radiokativitas buatan yang mengarah pada reaksi pemisahan inti (reaksi fisi) yang merupakan cikal bakal pembuatan bom atom (Robert, 2004).

\section{Molekul Senyawa Optis (Kiralitas)}

Ditemukan secara kebetulan oleh Louis Pateur yang lebuh dikenal sebagi ahli mikrobiologi walaupun dia memulai karirnya lebih dahulu sebagai seorang ahli kimia. Pasteur pada tahun 1848 mempelajari garam dari asam rasemat yang terdapat pada tong-tong anggur 
pada saat fermentasi dan dengan garam dari asam tatrat yang juga ditemukan pada tong-tong anggur, diketahui kedua garam tersebut memiliki proses pembuatan yang sama. Pengamatannya terhadap kedua garam tersebut menghasilkan sesuatu yang tidak terduga bahwa ternyata garam dari asam rasemat tidak bersifat optis aktif atau tidak dapat memutar bidang polarisasi berlainan dengan asam dari garam tatrat yang bersifat optis aktif (dapat memutar bidang polarisasi). Akhirnya Pasteur menghubungkan hasil penemuan dengan struktur geometri dari kedua senyawa tersebut dan menemukan adanya stuktur senyawa kanan dan kiri yang berhubungan seperti pada tangan kiri dan tangan kanan. Hal ini menunjukkan adanya suatu sifat kiralitas dari suatu senyawa. Meskipun penemuan Pasteur tentang berbagai pemisahan dalam bentuk kristal, terdapat dua faktor keberuntungan yakni 1) Garam natrium amonium dari asam rasemat, yang diuji merupakan satu-satunya garam yang dari asam kristal yang mengkristal dalam bentuk-bentuk bayangan yang terbalik yang dapat dibedakan dan dipisahkan secara mekanik. 2) Suhu $26^{\circ} \mathrm{C}$ pada waktu itu yang membuat dua senyawa kristal dapat terbentuk, karena jika di atas suhu tersebut semua kristal akan serupa dan tidak menunjukkan sifat optis. Hal ini karena Pasteur meletakkan botol yang berisi larutan garam tersebut di tirai jendela yang dingin di laboratoriummnya agar proese kristalisasi dapat terjadi (Robert, 2004).

\section{Struktur Kekule}

Serendipity terhadap struktur dari senyawa benzena terjadi pada tahun 1985 oleh seorang yang bernama Friedrich August Kekulé melalui mimpi. Kekulé bermimpi di atas sebuah bis di London tentang atom yang membentuk sebuah rantai, atom yang besar merangkul atom yang lebih kecil dan atom yang besar dapat menahan 3 atau bahkan empat atom lebih kecil. Mimpi tersebut menuntun Kekulé untuk mengusulkan bahwa atom-atom karbon tertentu dapat saling berhubungan dalam rantai-rantai atom, yang dihubungkan dengan atom hidrogen atau atom lainnya. Mimpi kedua terjadi ketika Kekulé tertidur di samping perapian di Ghent. Dia bermimpi tentang ular yang menggigit ekornya sendiri, yang menuntun Kekulé untuk mengusulkan struktur siklik dari benzena, dengan enam atom karbon dalam satu cincin (Robert, Royston M, 2004).

\section{Unsur-Unsur Kimia dan Sintesis Senyawa Organik}

Berikut ini adalah penemuan unsur-unsur kimia dan sintesis senyawa organik yang termasuk dalam serendipity (Robert, 2004): 1) Oksigen, ditemukan melalui pengamatan Joseph Priestley berkebangsaan Inggris dan Carl Wilhem Scheele, berkebangsaan Swedia, bahwa udara yang baru yang belum diketahui namanya dapat memadamkan nyalaapi dan lilin dan udara tesebut dapat membakar lagi lilin atau kayu tersebut. 2) lodin, penemuan tak sengaja oleh Courtois pada tahun 1811 ketika membersihkan endapan penyulingan kalium dari gangang laut diperoleh dengan asap kuat muncul adanya asap lembayung dari tong tersebut dan ketika berhubungan dengan udara dingin kemudian membentuk endapan kristal logam yang berwarna gelap, kemudian diteliti lagi oleh Sir Humpry Davy dan Joseph Louis Gay-Lussac dan mereka menamai unsur tersebut iodin. 3) Helium dan Gas mulia, melalui pengamatan terhadap gambar gerhana matahari, oleh J. Norman Lockyer pada tahun 1868, terlihat adanya garis-garis spektrum pada gambar tersebut yang menunjukkan adanya keberadaan suatu gas tertentu yang ada di matahari, kemudian diarahkan untuk meneliti keberadaan gas tersebut di bumi. Gas tersebut kemudian dikenal dengan nama Helium seperti nama matahari, dan penemuan terhadap gas Helium ini mengarahkan pada penemuan gas-gas mulia lainnya. 4) Sintesis Urea, pada tahun 1828 di Berlin Wöhler melakukan percobaan untuk membuat Ammonium Sianat murni dari Kalium Sianat dan Ammonium sulfat, ternyata hasil pemanasan dari kedua campuran gas tersebut menghasilkan kristal-kristal putih yang sama persis dengan urea yang ditemukan pada air seni manusia dan anjing. Selain itu bersama dengan Berzelius, bahwa urea dan ammonium Sianat yang dihasilkan dari amonium sianat tersebut adalah isomer (dalam bahasa Yunani diartikan memiliki bagian yang sama). 5) Polietilena, atau umunya dikenal dengan nama polimer, yang ditemukan tidak sengaja pada bulan Desember tahun 1985 oleh para ilmuwan kimia di ICl ( Imperial Chemical Industries) ketika mereka bekerja dengan Etilena dan mereka menemukan adanya padatan dam bentuk bubuk putih pada bejana reaksi yang kemungkinan terjadi sebagai akibat adanya kebocoran dari sambungan-sambungan pada peralatan mereka. 6) Eter Mahkota, penemuan Charles J. Pedersen pada tahun 1960an yang muncul sebagai akibat kontaminan di salah satu zat kimia yang digunakan dalam sebuah percobaan.

Hubungan Penalaran Ilmiah dengan Penemuan-Penemuan yang Tidak Disengaja (Serendipity) 
Berbagai serendipitious yang terjadi di dalam sains seperti pembahasan di atas telah memperlihatkan kepada kita bahwa ada banyak penemuan sains yang terjadi secara acak dan kebetulan (tidak disengaja) dapat dikatakan sebagai sesuatu keberuntungan dapat dikelompokkan sebagai serendipity murni seperti pada penisilin, dan dapat juga dikelompokkan sebagai pseudo serendipity yang memiliki pengertian penemuan yang tidak disengaja untuk sesuatu yang sedang dicari seperti pada struktur DNA pada gambar di atas seperti gambaran tipologi dari serendipity (De Rond, 2005): Berdasarkan tipologi serendipity diketahui perlu adanya suatu penalaran ilmiah yang terkait pada penemuan serendipity tersebut baik secara deduktif, induktif ataupun abduktif yang dapat mengarahkan kepada keberhasilan penemuan yang bermakna. Seperti dikemukan oleh penemu vitamin C SzentGyörgyi (De Rond, 2005) bahwa: "Penemuan adalah melihat sesuatu yang orang lain telah lihat, tapi berpikir sesuatu yang orang lain tidak pikirkan". Pada diri setiap ilmuwan yang terlibat adanya serendipity diketahui memiliki: memiliki pengetahuan yang signifikan dengan temuannya, memiliki sifat ingin tahu dan daya imajinasi yang tinggi, dan kemampuan berpikir cerdas dan kreatif. Hal ini sejalan dengan pendapat Mannoia (1980) bahwa:"Penemuan (discovery) merupakan pembentukan generalisasi konseptual teoritik tentang problem (fakta-fakta khusus yang diobservasi), dengan menggunakan logika abduktif, yaitu proses berpikir dari partikular ke generalisasi (teori) yang melibatkan kreativitas."

Hal ini juga ditekankan oleh Pasteur: "Bahwa dalam bidang pengamatan, yang namanya peluang emas hanya menyukai pikiran yang memang siap". Pada diri setiap ilmuwan yang menemukan serendipity mereka sama-sama memiliki sifat persepsi dan melalui proses pengamatan yang cermat terhadap suatu fenomena yang tak diharapkan dapat dimunculkan suatu penemuan yang benilai. Walaupun kita tidak dapat menepis adanya faktor keberuntungan bagi para ilmuwan tersebut untuk berada pada saat dan tempat yang tepat namun seperti yang dikemukakan oleh Sir Horace Walpole dalam kisahnya tentang tiga pangeran dari Serendip bahwa ketidaksengajaan dan kecerdikan selalu berada pada posisi yang sama (Robert, 2004). Sebab penemuan-penemuan yang tak dicari tetapi sangat berarti dapat terjadi karena ketidaksengajaan dan kecerdikan dari kalangan orang yang terdiri dari individu-individu yang memiliki bakat tertentu. Dengan demikian dapat kita harapkan adanya kemajuan teknologi dan berkembangnya pikiran manusia yang jauh lebih siap dari sebelumnya dapat mengubah ketidaksengajaan semacam itu yang dapat berubah menjadi hal-hal yang hebat melalui serendipity.

\section{Kesimpulan}

Diketahui jika berdasarkan tipologinya serendipity dibagi menjadi dua yakni yakni serendipity murni dan pseudo serendipity. Namun berdasarkan pada penalaran ilmiah, maka kita dapat mengelompokkan serendipity berdasarkan penalaran ilmiah sebagai berikut:(1) Serendipity yang terjadi sebagai akibat dari adanya pemahaman terhadap suatu kasus-kasus yang khusus menuju suatu kesimpulan umum yang terjadi yaitu suatu inferensi yang bersifat induktif yaitu yang melandasi pengujian hipotesis-hipotesis melalui serangkaian eksperimentasi dapat ditemukan pada serendipity: penicilin, baterei listrik, radioaktivitas;(2) Serendipity yang terjadi sebagai akibat dari adanya pemahaman terhadap suatu premis umum ke premis khusus yang terjadi yaitu suatu inferensi yang bersifat deduktif yang melandasi konstruksi/formulasi hipotesis dari suatu teori yang dipilih dapat ditemukan pada serendipity seperti pada: struktur DNA, struktur Kekule, Helium dan gas mulia, molekul senyawa optis; dan (3) Namun dapat dikatakan bahwa sebagian besar dari serendipity yang dipaparkan di sini termasuk dalam inferensi abduktif yang melandasi proses konstruksi teori berdasarkan fakta-fakta yang ada. Pada serendipity: vaksinasi cacar, elektromagnetisme, sinar X, oksigen, iodin, sintesis urea, politena dan eter mahkota.

\section{Daftar Pustaka}

Austin, J. H. (2003 [1978]). Chase, Chance and Creativity: The Lucky Art of Novelty. London: The MIT Press.

Arif ,Marlian (2016). Filsafat Sains Dalam Perspektif Pemikiran Islam . Jurnal Program Pascasarjana Universitas Islam Negeri Sumatera Utara Al-Lubb, Vol. 1, No. 1, 2016: 4366 
Bandura, A. (1982). The psychology of chance encounters and life paths. American Psychologist, 37: 747-755.

Bandura, A. (1998) Exploration of fortuitous determinants of life determinants of life paths. Psychological Inquiry, 9: 92-115.

Burt, R.S. (2004). Structural holes and good ideas. American Journal of Sociology, 110(2): 349-99.

Campanario, J.M. (1996). Using citation classics to study the incidence of serendipity in scientific discovery, Scientometrics, 37(1): 3-24.

De Rond, M. (2005).Working Paper: The Structure of Serendipity, UK : University of Cambridge.

Eka ,Fitrisa (2016). Pengaruh Pembelajaran Berbasis Proyek Untuk Melatihkan Keterampilan Proses Mahasiswa . Jurnal Pedagogia Issn 2089-3833 Volume. 5, No. 2, Agustus 2016

Ferguson, A. (1999). The lost land of serendip. Forbes Vol 164(8): 193-4.

Ghys, Ettiane.( 2012). The Butterfly Effect: $12^{\text {th }}$ Conggress on Mathemathical Education. Seoul, Korea: COEX.

Gunarti ,Winny (2013). Sains Dan Kreativitas: Pandangan Terhadap Pemikiran John Horgan Dalam "The End Of Science" . Jurnal Desain ISSN Online : 2339 - 0115

Hamid Sulhan (2015). Peran Kemajuan Sains Dan Teknologi Abad Kejayaan Islam Dan Implikasinya Terhadap Modernisasi Abad Kontemporer (Studi Analisis Kebijakan Politik Pendidikan Islam) . Jurnal Paradigma Volume 2, Nomor 1, November 2015: Issn 24069787

Kuhn, T.S. (1970). The Structure of Scientific Revolutions. Chicago: University of Chicago Press.

Mannoia, V.J. (1980). What is Science?: An introduction to the structure and methodology of science. Lahman, MD: University Press of America.

Merton, R. and Barber, E. (2004). The Travels and Adventures of Serendipity. Princeton, NJ: Princeton University Press.

Muksin ,Mochamad (2016). Islam Dan Perkembangan Sains \& Teknologi (Studi Perkembangan Sains Dan Teknologi Dinasti Abbasiyah) . Jurnal Teknologi \& Manajemen Informatika Volume 2, Nomor 4, Juni 2016.

Ratmawati ,Eris (2017). Pemahaman Hakikat Sains (Nos) Mahasiswa Tahun Ketiga Program Studi Pendidikan Kimia Universitas Negeri Malang . Jurnal Universitas Negeri Malang

Robert, Royston M.( 2010). Serendipity: Penemuan-Penemuan di Bidang Sains yang Tidak disengaja, Cetakan ke-6 Edisi Revisi. Bandung: Pakar Karya.

Rhisa (2015). Jejak-Jejak Perkembangan Sains Dan Teknologi Dalam Alqur'an . Jurnal Universitas Hasanuddin Makassar 90245

Tolson, J. (2004). A word's eventful journey. U.S. News \& World Report Vol 136(4): 51.

Watson, J.D. (1999 [1968]). The Double Helix. London: Penguin.

Watson, J.D. and Crick, F.H.C. (1953). A structure for deoxyribose nucleic acid, Nature (3), 171: 737-738. 